\title{
Seasonal and spatial variations in the nutrient limitation of bacterioplankton growth in the northwestern Mediterranean
}

\author{
Maria Montserrat Sala*, Francesc Peters, Josep M. Gasol, Carlos Pedrós-Alió, \\ Celia Marrasé, Dolors Vaqué
}

Departament de Biologia Marina i Oceanografia, Institut de Ciències del Mar-CMIMA (CSIC), P. Marítim 37-49, 08003 Barcelona, Spain

\begin{abstract}
Nutrient limitation of bacterioplankton growth was studied in the western Mediterranean Sea to determine its spatial and temporal variations. Shipboard microcosm experiments were performed in June 1995, June 1996 and September 1996. Seawater was amended with carbon (C, as glucose), nitrate $(\mathrm{N})$ and phosphate $(\mathrm{P})$, individually or in combination. The limiting nutrient was inferred from the combination that stimulated the highest bacterial production and generated the highest bacterial biomass in the experiments. The results of the experiments carried out along a coastal-to-open sea transect, with both surface and deep chlorophyll maximum depth waters (DCM), suggest that there is a strong variability in the factors limiting bacteria. While phosphorus was most often the limiting nutrient in the surface samples, at the DCM depths nitrogen or carbon limitation was also found. The surface waters of the open sea station were also studied during the 3 cruises to provide an estimate of seasonal variation of bacterial limitation. Phosphorus limitation was found in the 3 periods: very clear phosphorus limitation in September 1996, possible phosphorus limitation in June 1995 and possible co-limitation with carbon in June 1996. Our results show that phosphorus is the main nutrient limiting bacterioplankton growth in the NW Mediterranean. However, while phosphorus was usually the limiting nutrient in the surface layers, nitrogen and carbon limitation also occurred at other depths. Thus, seasonal and spatial variability in the nutrient limiting bacterial growth should be expected.
\end{abstract}

KEY WORDS: Nutrient limitation • Bacterioplankton · NW Mediterranean · Spatial variation . Temporal variation

Resale or republication not permitted without written consent of the publisher

\section{INTRODUCTION}

It is generally considered that nitrogen is the nutrient that limits primary productivity in most oceans (Codispoti 1989, Tyrrell \& Law 1997, Tyrrell 1999). However, an increasing number of studies show that phosphorus may limit primary production in some areas of the ocean, such as the Sargasso Sea (Wu et al. 2000), and iron can be limiting in high-nutrient, low-chlorophyll zones (Martin \& Fitzwater 1988, Coale et al. 1996,

*E-mail: msala@icm.csic.es
Landry et al. 1997, Boyd et al. 2000). Recent evidence points to phosphorus limitation in areas of the ocean that were thought to be limited mainly by nitrogen (Karl et al. 1998, Karl 1999, 2000).

There is growing evidence that the limiting nutrient in the Mediterranean Sea is phosphorus. The dissolved nitrogen to phosphorus ratio in the Mediterranean has been reported to be about 21 to 23 in the western part (Bethoux et al. 1992), and even higher in the eastern basin (Krom et al. 1991), which is quite different from the ratio of 15 found in the global ocean (Tyrrell 1999). Experimental studies in the eastern Mediterranean have always shown phosphorus limitation, both at 
coastal stations (Bonin et al. 1989) and in deep waters (Berland et al. 1990, Zohary \& Robarts 1998). In addition, experiments performed in the NW Mediterranean Sea coastal waters showed phosphorus as the limiting factor for phytoplankton growth (Jacques et al. 1973, Fiala et al. 1976).

Intimately connected to the nutrient limitation of primary production in the photic zone is the question of whether this nutrient limitation also applies to the growth and activity of heterotrophic bacteria. Until recently it was thought that available organic carbon was the limiting nutrient for heterotrophic bacterial growth in the oceans. However, in recent years, it has been recognised that heterotrophic bacteria are strong competitors of phytoplankton for inorganic nutrients (i.e. Thingstad \& Rassoulzadegan 1995) and that these inorganic nutrients may directly limit heterotrophic bacterial activity in some aquatic ecosystems (Kuparinen \& Heinanen 1993, Caron 1994, Kirchman 1994, Elser et al. 1995, Pomeroy et al. 1995, Rivkin \& Anderson 1997, Caron et al. 2000), including the Mediterranean (Zohary \& Robarts 1998). In the western part of this sea, the few existing studies on bacterioplankton limitation have been done at a single station off the Villefranche-sur-mer coast (Zweifel et al. 1993, Thingstad et al. 1998), and have always found phos-

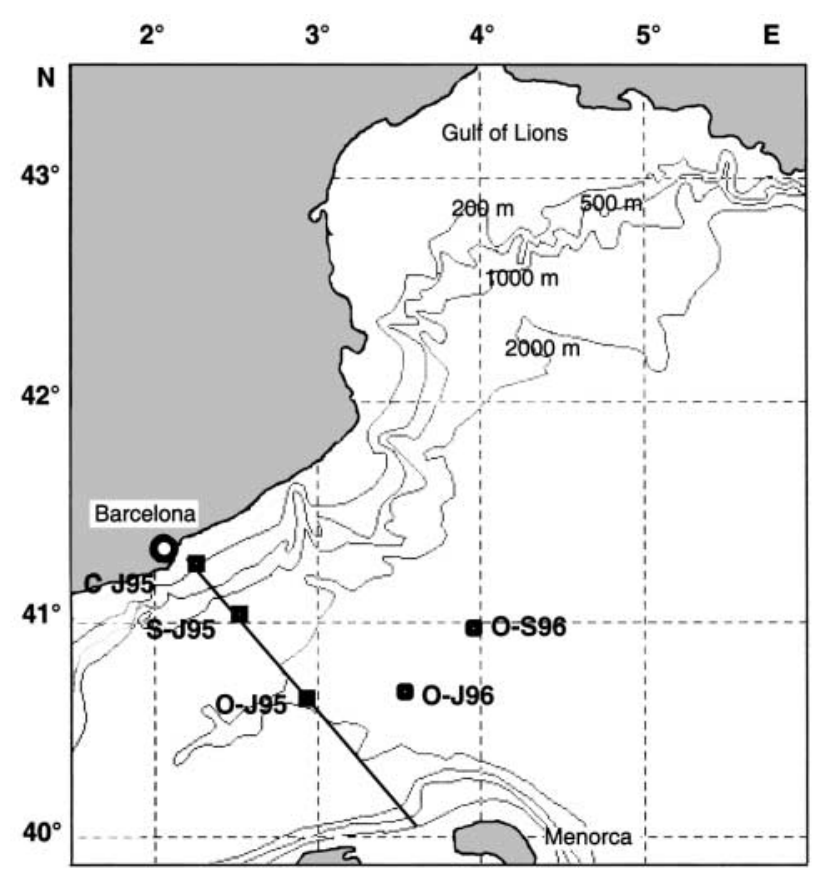

Fig. 1. Map of the northwestern Mediterranean Sea with the stations sampled during the 3 cruises. The transect was sampled in June 1995 (J95) and the stations were coastal (CJ95), slope (S-J95) and open sea (O-J95). Other open sea stations were sampled in June 1996 (O-J96) and September 1996 (O-S96) phorus deficiencies. The aim of our work was to test the existence of phosphorus limitation of heterotrophic bacterial growth in open waters of the western Mediterranean, and to determine whether there were variations in space and time.

In order to test this hypothesis, we designed several multifactorial experiments that consisted of adding inorganic nutrients (nitrate $[\mathrm{N}]$, phosphate $[\mathrm{P}]$ or both) and a source of carbon ( $\mathrm{C}$, as glucose), and monitoring the response of the microbial populations. This was done by measuring the rate of leucine incorporation into bacterial biomass and the changes in bacterial numbers. If the assumption that phosphorus was the limiting nutrient for the community held true, we would expect that addition of $\mathrm{P}$ alone would be enough to stimulate bacterial growth. We focused our study on heterotrophic bacterioplankton growth limitation (1) in the open sea, in both spring and autumn; (2) at 3 stations located within the main hydrographical features of the inshore-offshore gradient: the coastal area over the continental shelf, the slope and the open sea at depths $>2000 \mathrm{~m}$; and (3) both in surface waters and at the depth of the deep chlorophyll maximum (DCM).

\section{MATERIAL AND METHODS}

We established 2 types of shipboard microcosm experiments at a total of 5 stations in the CatalanoBalearic basin of the Mediterranean Sea (Fig. 1), 3 located in the open sea (Table 1), 1 above the shelf slope, and 1 above the coastal shelf.

During June 1996 and September 1996 we carried out microcosm experiments with surface water from an open ocean (open sea O) station. The experiments differed mainly in the combination of nutrient additions (Table 2). In June 1996 the treatments were K (control without additions), N (nitrate), NP (nitrate + phosphate), C(glucose) N, and CNP. In September, we had 8 treatments: K, C, N, P, CN, CP, NP and CNP. Each treatment was carried out in 2 replicate bottles.

On a cruise in June 1995 we established 6 microcosm experiments with waters from 3 stations placed in the transect between Barcelona and the channel between Mallorca and Minorca, which has been repeatedly studied in the last few years (e.g. Estrada et al. 1993, Pedrós-Alió et al. 1999). The 3 stations selected along the transect were chosen to represent the 3 main hydrographic zones: the shelf coastal waters (coastal C), the slope frontal zone (slope S) and the offshore open sea zone. Two depths were studied at each station: surface and DCM depth. Characteristics of phytoplankton and bacterioplankton production in the transect have been summarised elsewhere (Estrada 1996, Pedrós-Alió et al. 1999). Additions in the experiments 
Table 1. Characteristics of the stations sampled in the NW Mediterranean Sea. The transect was sampled in June 1995 (J95) and the stations were coastal (C-J95), slope (S-J95) and open sea (O-J95). Other open sea stations were sampled in June 1996 (O-J96) and September 96 (O-S96)

\begin{tabular}{|c|c|c|c|c|c|}
\hline Stn & Cruise & RV & $\begin{array}{l}\text { Latitude, } \\
\text { longitude }\end{array}$ & $\begin{array}{c}\text { Maximal } \\
\text { depth (m) }\end{array}$ & $\begin{array}{c}\text { Surface } \\
\text { temp. }\left({ }^{\circ} \mathrm{C}\right)\end{array}$ \\
\hline C-J95 & Varimed 95 & BIO 'Hespérides' & $\begin{array}{l}41^{\circ} 22^{\prime} 02^{\prime \prime} \mathrm{N} \\
02^{\circ} 17^{\prime} 30^{\prime \prime} \mathrm{E}\end{array}$ & 68 & 18.5 \\
\hline S-J95 & Varimed 95 & BIO 'Hespérides' & $\begin{array}{l}41^{\circ} 06^{\prime} 10^{\prime \prime} \mathrm{N} \\
02^{\circ} 26^{\prime} 13^{\prime \prime} \mathrm{E}\end{array}$ & 1114 & 18.5 \\
\hline O-J95 & Varimed 95 & BIO ‘Hespérides' & $\begin{array}{l}40^{\circ} 40^{\prime} 25^{\prime \prime} \mathrm{N} \\
02^{\circ} 52^{\prime} 00^{\prime \prime} \mathrm{E}\end{array}$ & 2093 & 18.5 \\
\hline O-J96 & Varimed 96 & BO 'García del Cid' & $\begin{array}{l}40^{\circ} 39^{\prime} 35^{\prime \prime} \mathrm{N} \\
03^{\circ} 00^{\prime} 20^{\prime \prime} \mathrm{E}\end{array}$ & 2048 & 20 \\
\hline O-S96 & Fronts 96 & BO 'García del Cid' & $\begin{array}{l}41^{\circ} 04^{\prime} 02^{\prime \prime} \mathrm{N} \\
03^{\circ} 50^{\prime} 49^{\prime \prime} \mathrm{E}\end{array}$ & 2413 & 21 \\
\hline
\end{tabular}

Table 2. Description of the enrichment experiments: treatments, sampling depths, duration of the incubations, temperature and volume of the experimental vessels. C: glucose; K: control without additions; N: nitrate; P: phosphate

\begin{tabular}{|c|c|c|c|c|c|}
\hline Stn & $\begin{array}{l}\text { Sampling } \\
\text { depth (m) }\end{array}$ & Treatments & $\begin{array}{l}\text { Incubation } \\
\text { (d) }\end{array}$ & $\begin{array}{l}\text { Incubation } \\
\text { temp. }\left({ }^{\circ} \mathrm{C}\right)\end{array}$ & $\begin{array}{c}\text { Incubation } \\
\text { volume (l) }\end{array}$ \\
\hline C-J95 & 0 & $\mathrm{~K}, \mathrm{C}, \mathrm{N}, \mathrm{P}, \mathrm{CNP}$ & 4 & 18.5 & 1 \\
\hline C-J95 & 50 & $\mathrm{~K}, \mathrm{C}, \mathrm{N}, \mathrm{P}, \mathrm{CNP}$ & 4 & 13 & 1 \\
\hline S-J95 & 0 & $\mathrm{~K}, \mathrm{C}, \mathrm{N}, \mathrm{P}, \mathrm{CNP}$ & 4 & 18.5 & 1 \\
\hline S-J95 & 50 & $\mathrm{~K}, \mathrm{C}, \mathrm{N}, \mathrm{P}, \mathrm{CNP}$ & 4 & 13 & 1 \\
\hline O-J95 & 0 & $\mathrm{~K}, \mathrm{C}, \mathrm{N}, \mathrm{P}, \mathrm{CNP}$ & 4 & 18.5 & 1 \\
\hline O-J95 & 50 & $\mathrm{~K}, \mathrm{C}, \mathrm{N}, \mathrm{P}, \mathrm{CNP}$ & 4 & 13 & 1 \\
\hline O-J96 & 5 & $\mathrm{~K}, \mathrm{~N}, \mathrm{NP}, \mathrm{CNP}$ & 5 & 20 & 5 \\
\hline O-S96 & 20 & $\mathrm{~K}, \mathrm{C}, \mathrm{P}, \mathrm{N}, \mathrm{CN}, \mathrm{CP}, \mathrm{NP}, \mathrm{CNP}$ & 4 & 21 & 5 \\
\hline
\end{tabular}

conducted in the transects were all $\mathrm{K}, \mathrm{C}, \mathrm{N}, \mathrm{P}$ and CNP (Table 2).

Experimental design. The experimental conditions are described in Table 2. For the 2 microcosm experiments carried out in 1996, duplicate 51 plastic carboys were filled with water. In June, we chose water from $5 \mathrm{~m}$ and in September from $20 \mathrm{~m}$. The carboys were filled during the night in order to avoid sunlight phytoplankton damage.

The carboys were incubated on deck in a $1 \mathrm{~m}^{3}$ tank with circulating surface seawater to maintain in situ temperatures. The tank was covered with a mesh to simulate the light intensity available at the sampled depths. Light intensity in the tank was regularly checked.

Nutrients were added daily to provide a final enrichment of $4 \mu \mathrm{M}$ nitrate $\left(\mathrm{NaNO}_{3}\right), 0.13 \mu \mathrm{M}$ phosphate $\left(\mathrm{NaH}_{2} \mathrm{PO}_{4} \cdot \mathrm{H}_{2} \mathrm{O}\right)$ and $40 \mu \mathrm{M}$ C-glucose. Subsamples were collected daily from each carboy to determine dissolved nutrient concentrations, chlorophyll $a(\operatorname{chl} a)$, bacterial abundance and bacterial activity.

The 1995 experiments differ in that bacteria were diluted and the predators were removed: the water was sequentially filtered through $200 \mu \mathrm{m}$ mesh, $1 \mu \mathrm{m}$ pore filters and $0.8 \mu \mathrm{m}$ Nuclepore filters, and this inoculum was diluted $1 / 10$ with $0.2 \mu \mathrm{m}$ filtered seawater. The resulting mixture was incubated in 11 sterile and acidrinsed Pyrex bottles for $4 \mathrm{~d}$ in the dark and at temperatures close to those in situ $\left(20^{\circ} \mathrm{C}\right.$ for surface and $15^{\circ} \mathrm{C}$ for DCM samples). The bottles were sampled daily for determination of bacterial numbers and bacterial activity.

Nutrients. Samples for inorganic nutrient determinations were taken daily in plastic bottles and frozen until analysis in the laboratory. Inorganic phosphorus, nitrate, nitrite and ammonium were analysed with an Evolution II (Alliance Instruments, Tecnova, France) autoanalyser according to the methodology of Grasshoff et al. (1983).

Bacterial abundance and production. Subsamples $(100 \mathrm{ml})$ were fixed with cold glutaraldehyde $(1 \%$ final concentration). Bacteria were stained with 4 ',6diamidino-2-phenylindole (DAPI) (final concentration $5 \mu \mathrm{g} \mathrm{ml}^{-1}$ ) and filtered on black polycarbonate filters ( 0.2 pore diameter) following the procedure described by Porter \& Feig (1980). Cells on the filters were counted with a Nikon Labophot epifluorescence 
microscope at $1250 \times$ magnification. Cell volumes for the 1995 samples were determined with an image analysis system measuring at least 200 cells sample s $^{-1}$ (Massana et al. 1997).

The rate of incorporation of tritiated leucine into macromolecules was measured for estimation of bacterial activity, following the method of Kirchman et al. (1985) with the modifications suggested by Smith \& Azam (1992). Tritiated leucine (151 $\mathrm{mCi} \mathrm{mmol}^{-1}$, Amersham) was brought to a concentration of $1 \mu \mathrm{M}$ and mixed with non-radioactive leucine at 10\% hot:90\% cold, and dispensed (final concentration $40 \mathrm{nM}$ ) to $1.2 \mathrm{ml}$ of sample. This concentration was enough to saturate incorporation according to the tests done during the first cruise. Three replicates and 2 blanks killed with trichloroacetic acid (TCA) (5\% final concentration) per sample were incubated for 1 to $2 \mathrm{~h}$ in the dark at in situ temperature. The incubation was stopped with TCA (5\% final concentration). Samples were rinsed twice by centrifugation in 5\% TCA and then counted in a Packard scintillation counter after addition of Optiphase Hisafe II scintillation cocktail (Optiphase, Hipahase 2, Wallac, UK).

For the evaluation of the nutrient deficiency of bacterial cells we calculated 3 different indicators: the specific growth rate, the potential bacterial abundance or biovolume reached at the end of the experiment and the integrated bacterial activity. The use of these 3 parameters has been shown to provide useful information in the study of the limitation of microheterotrophic sources by resource abundance in Antarctic waters (CalderónPaz 1997) or in freshwaters (Eriksson \& Pedrós-Alió 1990). Specific growth rates were determined as the slope of simple linear regressions of log-transformed abundance versus time during exponential growth. We defined potential biovolume as the maximal abundance reached in each culture, multiplied by the cellular volume of the bacterial cells at the end of the experiment. In the experiments of 1996, we did not measure bacterial cell size and we thus used potential abundance, the maximal abundance reached in each culture. Total integrated leucine incorporation was expected to reflect the whole synthesis of protein throughout each experiment and was calculated as the integrated area of the leucine incorporation versus time.

\section{RESULTS}

\section{Spring versus autumn variations in the open sea station}

Concentrations of inorganic nutrients were quite similar in the 2 periods studied (Table 3), leading to very similar nitrogen to phosphorus ratios at the start of both experiments: 13.4 (June) and 10.4 (September). Bacterial concentrations were higher in June than in September. Leucine incorporation rates, on the contrary, were about 5 times higher in September (194 pmol $\mathrm{l}^{-1} \mathrm{~h}^{-1}$ ) than in June $\left(40 \mathrm{pmol} \mathrm{l}^{-1} \mathrm{~h}^{-1}\right)$, and bacterial growth rates were thus much higher in September than in June.

Both in June and September, inorganic phosphorus was generally below $0.2 \mu \mathrm{M}$ in the treatments with no $\mathrm{P}$ addition (Figs. 2a \& 3a). Treatments with $\mathrm{P}$ addition showed an accumulation of phosphorus until a plateau was reached. The levels of this plateau were near $4 \mu \mathrm{M}$ in NP in June and close to $1 \mu \mathrm{M}$ for the $\mathrm{P}, \mathrm{CP}$ and NP treatments in September. The exceptions to this clear trend were the CNP treatments, where phosphorus decreased soon after the addition and remained low throughout the experiments. Total inorganic nitrogen $\left(\mathrm{NH}_{4}+\mathrm{NO}_{3}+\mathrm{NO}_{2}\right)$ remained below $4 \mu \mathrm{M}$ in the treatments where $\mathrm{N}$ was not added (Figs. $2 \mathrm{~b} \& 3 \mathrm{~b}$ ). In the treatments with added $\mathrm{N}$, the concentration increased to values near 30 (June) or $20 \mu \mathrm{M}$ (September). As in the case of $\mathrm{PO}_{4}$ concentration, the only exception to this clear trend was the CNP treatment, where, after the first addition, nitrogen decreased to values around $1 \mu \mathrm{M}$.

Bacterial abundance (Figs. 2c \& 3c) in the CNP treatments showed a clear increase up to the second day $\left(7.9 \times 10^{6}\right.$ and $3.8 \times 10^{6}$ bacteria $\mathrm{ml}^{-1}$ in June and September, respectively), when they reached a plateau. A decrease was observed after Day 4 in June down to $5.0 \times 10^{5}$ bacteria $\mathrm{ml}^{-1}$. We found no clear differences among the other treatments in June, when bacterial concentrations varied between $1 \times 10^{6}$ and $3 \times 10^{6}$ bacteria $\mathrm{ml}^{-1}$. In September, however, treatments with $\mathrm{P}$ addition $(\mathrm{P}, \mathrm{CP}, \mathrm{NP})$ showed slightly higher concentrations of bacteria than the treatments without $\mathrm{P}$ addition.

Table 3. Initial values of different parameters in experiments carried out in June and September 1996. Chl a: chlorophyll a

\begin{tabular}{|lccccccc|}
\hline Expt & $\begin{array}{c}\mathrm{Chl} \mathrm{a} \\
\left(\mu \mathrm{g} \mathrm{l}^{-1}\right)\end{array}$ & $\begin{array}{c}\mathrm{PO}_{4} \\
(\mu \mathrm{M})\end{array}$ & $\begin{array}{c}\mathrm{NO}_{3} \\
(\mu \mathrm{M})\end{array}$ & $\begin{array}{l}\mathrm{NO}_{2} \\
(\mu \mathrm{M})\end{array}$ & $\begin{array}{r}\mathrm{NH}_{4} \\
(\mu \mathrm{M})\end{array}$ & $\begin{array}{c}\text { Bacterial } \\
\text { abundance } \\
\left(\text { cells ml }^{-1}\right)\end{array}$ & $\begin{array}{c}\text { Leu incorporation } \\
\text { rate }\left(\mathrm{pmol}^{-1} \mathrm{~h}^{-1}\right)\end{array}$ \\
\hline Jun 1996 & 0.09 & 0.08 & 0.28 & 0.04 & 0.75 & $7.08 \times 10^{5}$ & 40 \\
Sep 1996 & 0.35 & 0.12 & 0.21 & 0.06 & 0.98 & $5.27 \times 10^{5}$ & 194 \\
\hline
\end{tabular}




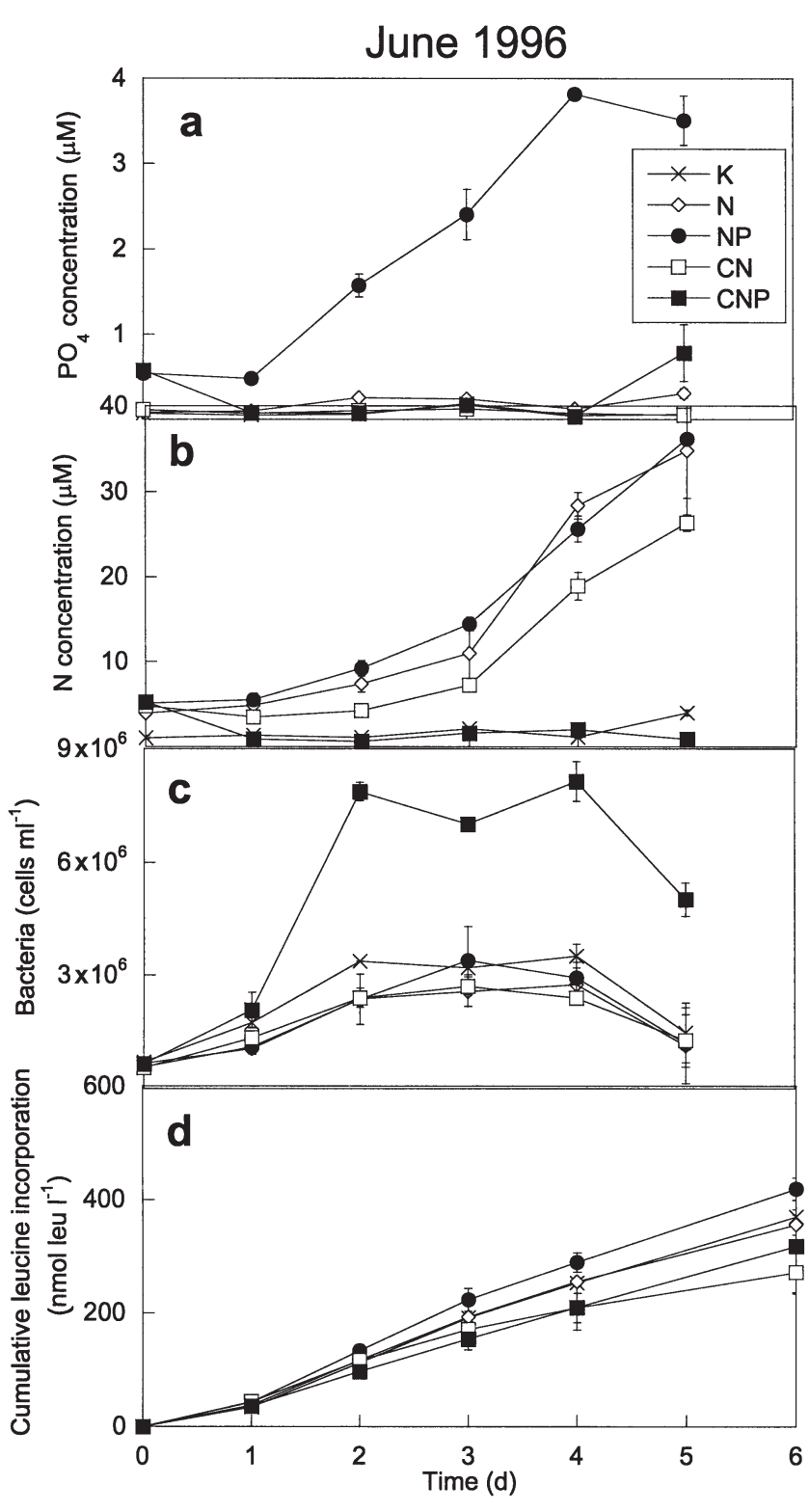

Fig. 2. (a) Evolution of $\mathrm{PO}_{4}$ concentration, (b) nitrogen concentration, (c) bacterial abundance and (d) cumulative leucine incorporation in the experiment of June 1996. Bars show standard deviation of 2 replicate bottles. Treatments are control $(\mathrm{K})$, nitrate addition $(\mathrm{N})$, nitrate and phosphate addition (NP), carbon (glucose) and nitrate addition (CN), and glucose, nitrate and phosphate additions (CNP)

Bacterial activity, presented as the cumulative leucine incorporation, increased in June in all treatments, regardless of the type of addition, but only NP showed values slightly higher than the control (Fig. 2d). In September (Fig. 3d), cumulative leucine incorporation was always higher in the $\mathrm{P}$ additions, and the highest levels were always observed in the CNP treatment.

We used 3 different parameters to test for nutrient deficiency: specific growth rate, potential abundance,
September 1996

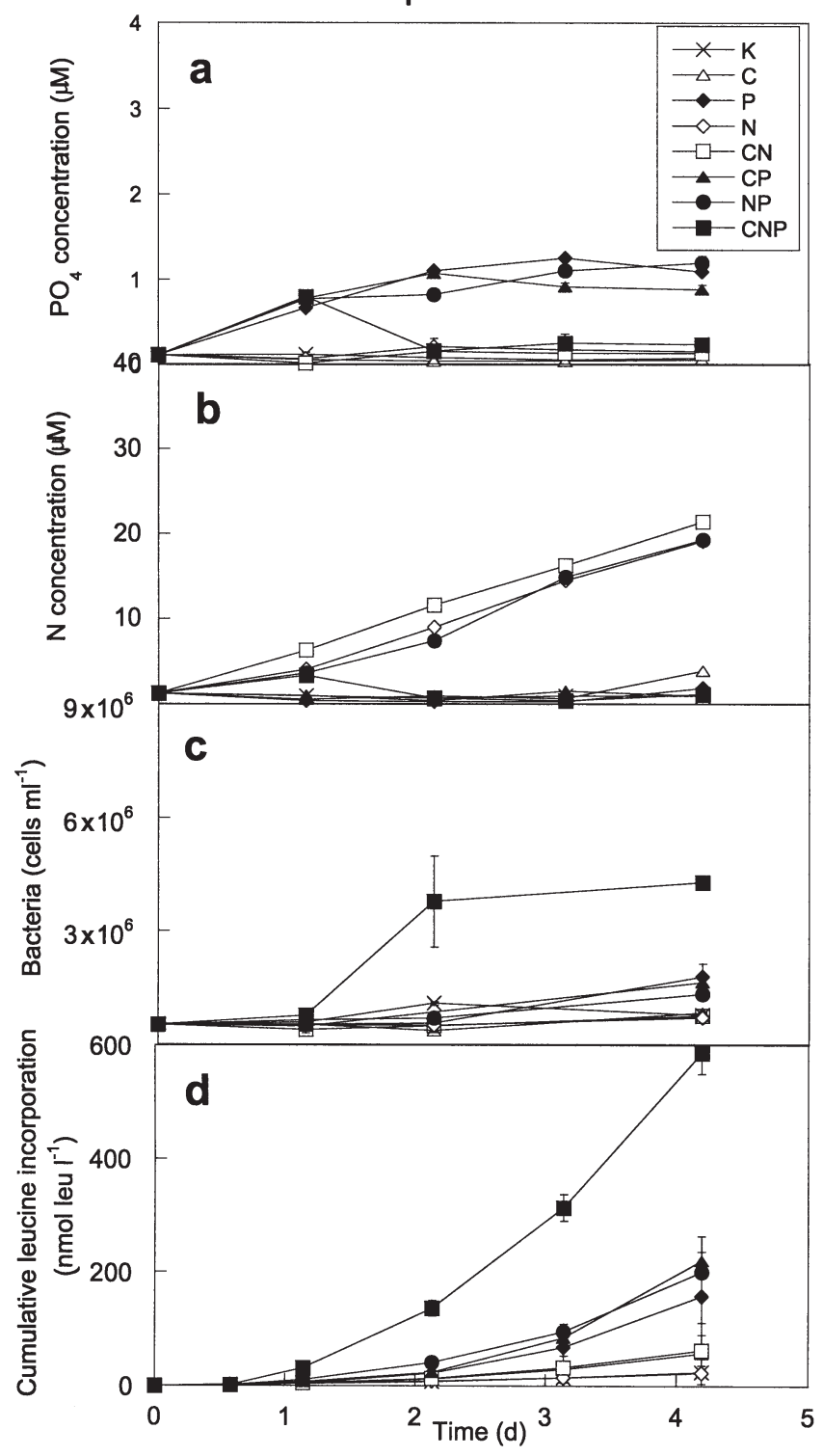

Fig. 3. (a) Evolution of $\mathrm{PO}_{4}$ concentration, (b) nitrogen concentration, (c) bacterial abundance and (d) cumulative leucine incorporation in the experiment of September 1996. Bars show standard deviation of 2 replicate bottles. Treatments are as in Fig. 2

and integrated leucine incorporation (Fig. 4). In both June and September, CNP treatments showed the highest specific growth rates and potential abundance. CNP treatments also had the highest integrated leucine incorporation in September. All parameters tended to be higher in the treatments containing P. Differences among treatments were tested statistically with an ANOVA for each of the 3 nutrients and for the combinations of 2 nutrients. For each analysis, treatments were split into 2 groups: with and without the nutrient amendment. Table 4 


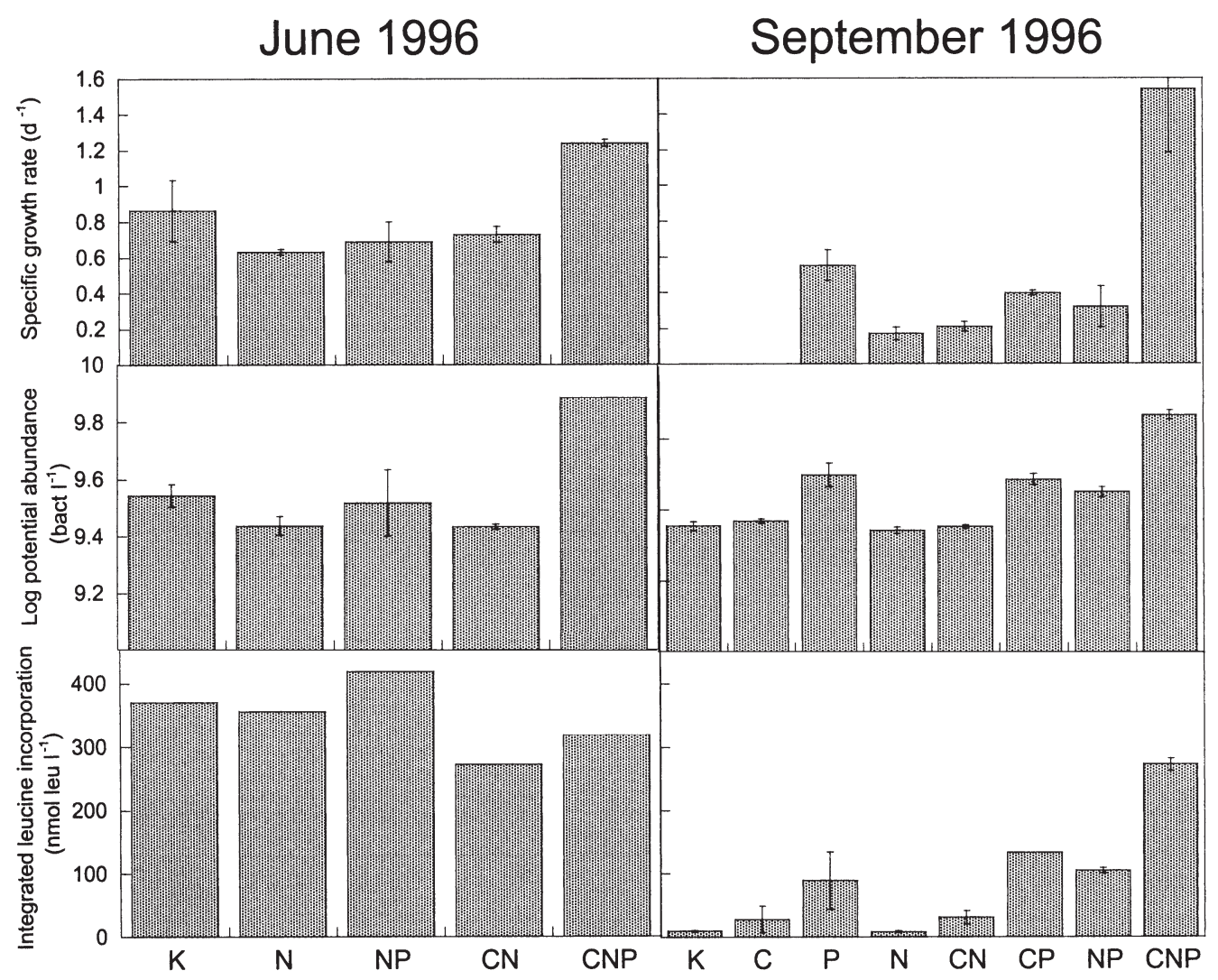

Fig. 4. Parameters calculated to evaluate nutrient limitation of bacterioplankton (bact) growth in the experiments performed in June and September 1996. Specific growth rate is the slope of simple linear regressions of log-transformed abundance with time during exponential growth. Potential abundance is the maximal abundance reached in each culture. Integrated leucine incorporation is the integrated area of the leucine incorporation up to the point of maximal cell abundance. Error bars are the standard deviation of 2 replicate treatments

shows the amendments that produced a significant increase in one or more of the 3 parameters, with their respective levels of significance. We considered that a nutrient was limiting when 2 or more of the 3 parameters showed significant changes after addition. If an increase was detected in only one parameter, we indicate that a possible limitation by that nutrient occurred. In June, the CNP additions caused highly significant increases in specific growth rate and potential abundance. Since NP showed only a slightly significant increase in potential abundance, we suspect that there was a limitation of carbon and phosphorus in that month even though we did not test that particular combination.

In September we had a clear phosphorus limitation since all parameters were significantly higher in the treatments in which $\mathrm{P}$ was added. A second limiting nutrient was carbon, which in combination with phosphorus caused significant increases in potential abundance and integrated production.

Table 4. Additions, or combination of additions, that elicited higher bacterial specific growth rates, potential abundances or integrated bacterial activity in the experiments performed in June and September 1996. Results of a 1-way ANOVA (see text). Limitation by a nutrient was diagnosed when at least 2 of the parameters were significantly different. A possible limitation is indicated when only one of the parameters was significantly higher. ns: none of the nutrient additions caused a significant increase in the parameter; ${ }^{*} \mathrm{p}<0.05 ;{ }^{* *} \mathrm{p}<0.01 ;{ }^{* * *} \mathrm{p}<0.001$

\begin{tabular}{|c|c|c|c|c|}
\hline Month & Specific growth rate & Potential abundance & Integrated production & Diagnosis \\
\hline Jun 1996 & $\mathrm{CNP}^{* *}$ & $\mathrm{CNP}^{* * *}, \mathrm{NP}^{*}$ & ns & $\mathrm{P}, \mathrm{CP}$ possible \\
\hline Sep 1996 & $\mathrm{P}^{*} \mathrm{CNP}^{* * *}$ & $\mathrm{P}^{* *}, \mathrm{CP}^{* *}, \mathrm{CNP}^{* * *}$ & $\mathrm{P}^{* * *}, \mathrm{CP}^{* * *}, \mathrm{CNP}^{* * *}$ & $\mathrm{P}$ \\
\hline
\end{tabular}




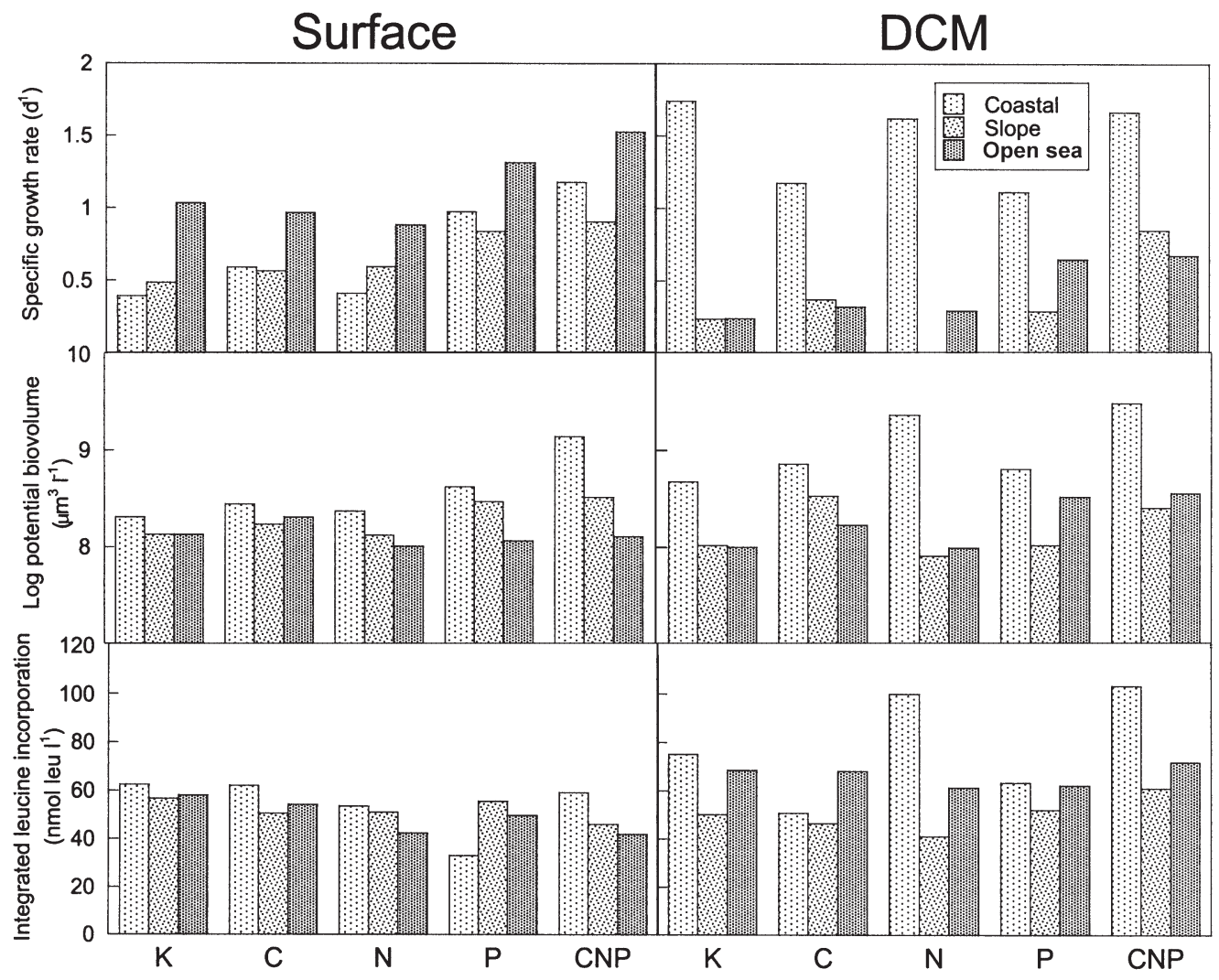

Fig. 5. Parameters calculated to evaluate nutrient limitation of bacterioplankton growth in the experiments performed at the surface and at the deep chlorophyll maximum (DCM) depth of the stations situated in the coastal, slope and open sea zone. Treatments are as in Fig. 2. Specific growth rate is the slope of simple linear regressions of log-transformed abundance with time during exponential growth. Potential abundance is the maximal abundance reached in each culture. Integrated leucine incorporation is the integrated area of the leucine incorporation up to the point of maximal biomass

\section{Spatial variation}

Six bioassays at 2 depths (surface and DCM) at 3 stations along an inshore-offshore transect were performed in June 1995. As in the seasonal comparison above, 3 different parameters were used as indicators of nutrient deficiency: specific growth rate, potential biovolume (in this case we had estimates of bacterial cell size), and integrated production. Fig. 5 shows the average results of these 3 different parameters in all the samples. In this case there were no replicate bottles, as we preferred to carry out more experiments with different samples rather than spend our efforts on replicated bottles that, as can be seen in Figs. $2 \& 3$, tend to be quite close. The time course of the different parameters evolved as in the previous experiments, and is thus not detailed here.

Without nutrient additions, we found the highest specific growth rates, potential biovolume and integrated bacterial production at the DCM depth of the coastal station. Differences among treatments were tested statistically as explained above. For each of these analyses, treatments were split into 2 groups: with the nutrient amendment $(\mathrm{n}=2)$ and without the nutrient amendment $(\mathrm{n}=3)$. Addition of $\mathrm{P}$ (Table 5) caused significant increases in specific growth rates in 4 out of 6 samples. Differences were significant for all surface samples, but only at the open sea station for the DCM samples. Altogether, it appeared that the effects of adding $P$ increased from coastal to open sea stations. $\mathrm{P}$ also caused significant increases in potential biovolume at the slope-surface station and in the open sea DCM sample. $\mathrm{N}$ amendments only caused significant increases at the coastal DCM station, in both potential biovolume and integrated production. Finally, C addition caused only a significant increase in the potential biovolume of the slope DCM sample.

As before, we considered that a nutrient was limiting when 2 or more of the 3 parameters caused significant differences after its addition. This was the case for phosphorus in the slope-surface and open sea DCM samples, and a possible phosphorus limitation in the coastal surface and open sea surface samples. We found nitrogen limitation in 1 of the 6 samples, the coastal DCM, and a possible carbon limitation at the slope DCM station. 
Table 5. Additions, or combination of additions, that elicited higher bacterial specific growth rates, potential biovolumes or integrated bacterial activity in the experiments performed in 1995 in 3 stations (coastal, slope and open sea) situated in an inshore-offshore transect. Results of a 1-way ANOVA (see text). Experiments were performed both at the surface and at the deep chlorophyll maximum (DCM) depth. Limitation by a nutrient was diagnosed when at least 2 of the parameters were significantly different. A possible limitation is indicated when only one of the parameters was significantly higher. ns: none of the nutrient additions caused a significant increase of the parameter; ${ }^{*} \mathrm{p}<0.05_{i}{ }^{* *} \mathrm{p}<0.01 ;{ }^{* * *} \mathrm{p}<0.001$

\begin{tabular}{|c|c|c|c|c|c|}
\hline Stn & Depth & Specific growth rate & Potential biovolume & Integrated production & Diagnosis \\
\hline \multirow[t]{2}{*}{ Coastal } & Surface & $\mathrm{P}^{*}$ & ns & ns & P possible \\
\hline & DCM & ns & $\mathrm{N}^{* *}$ & $\mathrm{~N}^{*}$ & $\mathrm{~N}$ \\
\hline \multirow[t]{2}{*}{ Slope } & Surface & $\mathrm{P}^{* *}$ & $\mathrm{P}^{* *}$ & ns & $\mathrm{P}$ \\
\hline & DCM & ns & $\mathrm{C}^{* *}$ & ns & C possible \\
\hline \multirow[t]{2}{*}{ Open sea } & Surface & $\mathrm{P}^{*}$ & ns & ns & P possible \\
\hline & DCM & $\mathrm{P}^{* *}$ & $\mathrm{P}^{* *}$ & ns & $\mathrm{P}$ \\
\hline
\end{tabular}

\section{DISCUSSION}

The aim of our study was to determine whether growth of the heterotrophic bacterial populations of the western Mediterranean Sea was phosphorus limited, and whether this limitation varied in space and time. We consider that a nutrient is limiting bacterial growth when the availability of that nutrient is low relative to the demand of the bacterial cells (Redfield 1958, Cotner et al. 1997). This was expressed as an increase of bacterial growth after the addition of the nutrient alone or in combination with other nutrients. We used 3 indicators of nutrient defficiency: growth rate, cumulative leucine incorporation and potential biomass achieved. Nutrient defficiency can affect in different ways the growth and metabolism of bacteria. If the actual growth rate is lower than the maximal growth rate, then the nutrient available is obviously limiting bacterial growth. A second possibility is that the growth rate is not affected but that the final biomass yield may be lower than the theoretical potential. This would be detected in our bioassays by a lower cumulative leucine incorporation or by a lower potential biomass achieved at the end of the experiments. These 3 indicators combine information from different effects of nutrients and integrate the response of the populations through the whole growth curve. Therefore, they are a sensitive tool to detect nutrient deficiency.

After the enrichment experiments, surface waters of the open sea stations showed that phosphorus was the limiting nutrient for heterotrophic bacterioplankton growth for the 3 periods of sampling: June 1995, June 1996 and September 1996. This limitation was found with several degrees: clear phosphorus limitation in September 1996, possible phosphorus limitation in June 1995, and possible phosphorus co-limitation with carbon in June 1996. We found that, regardless of the year or season, phosphorus was limiting bacterioplankton growth. Previous studies at a NW Mediter- ranean coastal station during summer have always shown a phosphorus limitation of bacterioplankton (Thingstad et al. 1998), short turnover rates of phosphorus (Dolan et al. 1995), and phosphorus limitation of Synechococcus sp. growth (Vaulot et al. 1996); the same has also been observed in autumn (Hagström et al. 2001). In summer a coastal station in Blanes Bay also showed a phosphorus-limited plankton in mesocosm experiments (Vidal \& Duarte 2000). In the NE Mediterranean, bacteria and phytoplankton growth has been shown to be phosphorus limited in winter (Zohary \& Robarts 1998), although no other studies have been published from other seasons.

There seemed to be a phosphorus or possible phosphorus limitation in all the samples taken at the surface of the stations in the transect analysed in June 1995. These observations are in agreement with the results obtained in similar enrichment experiments in the surface seawater of a coastal station (Zweifel et al. 1993, Thingstad et al. 1998, Hagström et al. 2001). At the DCM depth, however, such a clear pattern could not be detected. We found possible limitation by all nutrients: nitrogen at the coastal station, carbon at the slope station and phosphorus at the open sea stations. A well-developed DCM is a characteristic of the Mediterranean Sea during a large part of the year (Estrada 1985, Estrada et al. 1993). It can be explained by the reduced physical losses and the significant phytoplankton growth due to simultaneous availability of nutrients and light. Phytoplankton compete with bacteria for inorganic nutrients, and therefore higher phytoplankton concentrations could lead to a higher inorganic limitation of bacterial growth. The chl a concentration did not differ greatly among the stations, varying from $0.6 \mu \mathrm{g} \mathrm{l}^{-1}$ at the coastal station to $0.8 \mu \mathrm{g} \mathrm{l}^{-1}$ at the slope and open sea stations (Pedrós-Alió et al. 1999). However, results of samples taken in the transect on the September 1996 cruise showed clear differences in the size of the algal populations at the different stations. The open sea station showed the lowest 
concentrations of nanophytoplankton and the highest of Prochlorococcus sp. These small phototrophic bacteria can compete more efficiently with heterotrophic bacteria for nutrients. A possible explanation for the variability in the nutrient that was limiting heterotrophic bacterial growth in the DCM could be found in the sporadic instabilities of the DCM that can provide nutrient inputs from deeper layers.

The slope DCM sample showed no limitation by any inorganic nutrient; rather, it showed a possible carbon limitation. Pedrós-Alió et al. (1999) showed that bacteria from the slope station had higher growth rates than those from the coastal or open sea stations, perhaps due to small-scale fertilisation events associated with the slope front. Inorganic nutrient inputs from this front may eliminate the inorganic nutrient limitation of bacterioplankton growth and eventually, perhaps, lead to a shift to carbon limitation.

Finally, coastal DCM waters did not show clear phosphorus limitation, whereas nitrogen limitation was found. It may be possible that terrestrial phosphorus inputs can alter the nitrogen to phosphorus ratio and then induce nitrogen limitation of bacterioplankton growth at this site, which was located on the continental shelf. Diel variations in bacterial activity and dissolved organic carbon (DOC) concentrations were detected at the slope and open sea stations of this transect (Gasol et al. 1998), suggesting an algal-bacterial coupling at these stations, but not at the coastal station. This suggests that bacteria at the coastal station depend largely on allochthonous organic carbon.

Our enrichment bioassays have shown that phosphorus is the most likely nutrient to become limiting to the heterotrophic bacterioplankton in the surface layer, and that this occurs in different seasons, at different depths and at stations with different degrees of coastal influence. In the DCM we found phosphorus, nitrogen and possible carbon limitation at different stations. It is not possible to generalise the existence of a given limitation in these zones since they probably vary at short time intervals, responding to variations in nutrient concentrations driven by small-scale physical phenomena. It seems likely that the DCM is a very active zone, where heterotrophic bacteria co-exist with several phytoplankton species with different degrees of affinity for nutrients, which can act as competitors and modify the bacterial nutrient environment. Additionally, inputs from deeper layers can alleviate the deficiency of one nutrient and probably create a different deficiency. We can imagine that this must be a rather variable environment. Additional studies on bacterioplankton growth in this layer with a higher resolution in time and space seem promising, even though it appears that bacterioplankton diversity is quite homogeneous in this layer over large spatial scales, at least during the summer (Acinas et al. 1997). The study of this variability would require the search for appropriate direct and quick limitation indicators (e.g. Berdalet et al. 1996, Sala et al. 2001), which would avoid the use of long incubation experiments during which the community composition typically changes (Massana et al. 2001 and references therein). The bacterioplankton of the oligotrophic Mediterranean Sea live in a dynamic equilibrium in which slight changes in grazing pressure, competition and nutrient concentrations can shift the communities from one type of nutrient limitation to another.

Acknowledgements. We thank the captains, crews and chief scientists (Marta Estrada, Miquel Alcaraz and Anna Sabatés) of research vessels BO 'García del Cid' and BIO 'Hespérides'. We are also grateful to Kristine Lysnes, Laura Arin and Mercedes Castaño for their technical help and to Jarone Pinhassi for fruitful discussions. Funding was provided by the Spanish CICYT projects AMB94-0853 and MAR98-0932, and the EU project BIOHAB (EVK3-CT99-00015) and NATP (EVK3-CT2000-00022). This is ELOISE contribution no. 263/40.

\section{LITERATURE CITED}

Acinas SG, Rodríguez-Valera F, Pedrós-Alió C (1997) Spatial and temporal variation in marine bacterioplankton diversity as shown by RFLP fingerprinting of PCR amplified 16S rDNA. FEMS Microbiol Ecol 24:27-40

Berdalet E, Marrasé C, Estrada M, Arin L, MacLean ML (1996) Microbial community responses to nitrogen- and phosphorus-deficient nutrient inputs: microplankton dynamics and biochemical characterization. J Plankton Res 18:1627-1641

Berland BR, Maestrini SY, Burlakova ZP, Georgieva L, Kholodov VY, Krupatkina DK (1990) Limitation de la croissance algale dans les eaux ultra-oligotrophes de la mer du Levant (Mediterrannée orientale). Mem Biol Mar Oceanogr 18:5-28

Bethoux JP, Morin P, Madec C, Gentili B (1992) Phosphorus and nitrogen behaviour in the Mediterranean sea. DeepSea Res 39:1641-1654

Bonin DJ, Bonin MC, Berman T (1989) Mise en évidence expérimentale des facteurs nutritifs limitants de la production du micro-nanoplancton et de l'ultraplankton dans une eau côtiere de la Méditerranée orientale (Haïfa, Israël). Aquat Sci 51:129-152

Boyd PW, Watson AJ, Law CS, Abraham ER and 31 others (2000) A mesoscale phytoplankton bloom in the polar Southern Ocean stimulated by iron fertilization. Nature 407:695-702

Calderón-Paz I (1997) Ecología de las bacterias heterotróficas en ecosistemas planctónicos. PhD thesis, Universitat de Barcelona

Caron DA (1994) Inorganic nutrients, bacteria and the microbial loop. Microb Ecol 28:295-298

Caron DA, Lim EL, Sanders RW, Dennett MR, Berninger UG (2000) Responses to bacterioplankton and phytoplankton to organic carbon and inorganic nutrients additions in contrasting oceanic ecosystems. Aquat Microb Ecol 22: 175-184

Coale KH, Johnson KS, Fitzwater SE, Gordon RM and 15 others (1996) A massive phytoplankton bloom induced by 
an ecosystem-scale iron fertilization experiment in the equatorial Pacific Ocean. Nature 383:495-501

Codispoti LA (1989) Phosphorus vs nitrogen limitation of new and export production. In: Berger WH, Smetacek VS, Wefer G (eds) Productivity of the ocean: present and past. Report of the Dahlem Workshop on Productivity of the Ocean, Present and Past, Berlin 1988, April 24-29. Wiley, New York, p 377-408

Cotner JB, Ammermann JW, Peele ER, Bentzen E (1997) Phosphorus-limited bacterioplankton growth in the Sargasso Sea. Aquat Microb Ecol 13:141-149

Dolan JR, Thingstad TF, Rassoulzadegan F (1995) Phosphate transfer between microbial size-fractions in Villefranche Bay (NW Mediterranean sea), France in autumn 1992. Ophelia 41:71-85

Elser JJ, Stabler LB, Hasset RP (1995) Nutrient limitation of bacterial growth and rates of bacterivory in lakes and oceans: a comparative study. Aquat Microb Ecol 9: 105-110

Eriksson C, Pedrós-Alió C (1990) Selenium as a nutrient for freshwater bacterioplankton and its interactions with phosphorus. Can J Microbiol 36:475-483

Estrada M (1985) Deep phytoplankton and chlorophyll maxima in the Western Mediterranean. In: MoraitouApostolopoulou M, Kiortsis M (eds) Mediterranean marine ecosystems. Plenum Press, New York, p 247-277

Estrada M (1996) Primary production in the northwestern Mediterranean. Sci Mar 60:55-64

Estrada M, Marrasé C, Latasa M, Berdalet E, Delgado M, Riera T (1993) Variability of deep chlorophyll maximum in the Northwestern Mediterranean. Mar Ecol Prog Ser 92: 289-300

Fiala M, Cahet G, Jacques G, Neveux J, Panousse M (1976) Fertilisation de communautés phytoplanktoniques, I. Cas d'un milieu oligotrophe: mediterranée nord-occidentale. J Exp Mar Biol Ecol 24:151-163

Gasol JM, Doval MD, Pinhassi J, Calderón-Paz JI and 3 others (1998) Diel variations in bacterial heterotrophic production in the Nortwestern Mediterranean Sea. Mar Ecol Prog Ser 164:125-133

Grasshoff K, Ehrhardt M, Kremling K (1983) Methods on seawater analysis, 2nd edn. Verlag Chemie, Weinheim

Hagström Å, Pinhassi J, Zweifel UL (2001) Marine bacterioplankton show bursts of rapid growth induced by substrate shifts. Aquat Microb Ecol 24:19-115

Jacques G, Cahet G, Fiala M, Panousse M (1973) Enrichissement de communautés phytoplanctoniques néritiques de méditerranée nord occidentale. J Exp Mar Biol Ecol 11: 287-295

Karl DM (1999) A sea of change: biogeochemical variability in the North Pacific Subtropical Gyre. Ecosystems 2:181-214

Karl DM (2000) Phosphorus, the staff of life. Nature 406:31-32

Karl DM, Hebel DV, Björkman H, Letelier RM (1998) The role of dissolved organic matter release in the productivity of the oligotrophic North Pacific Ocean. Limnol Oceanogr 43:1270-1286

Kirchman DL (1994) The uptake of inorganic nutrients by heterotrophic bacteria. Microb Ecol 28:255-271

Kirchman DL, K'nees E, Hodson R (1985) Leucine incorporation and its potential as a measure of protein synthesis by bacteria in natural aquatic systems. Appl Environ Microbiol 49:599-607

Krom MD, Kress N, Brenner S, Gordon LI (1991) Phosphorus limitation of primary productivity in the eastern Mediterranean Sea. Limnol Oceanogr 36:424-432

Kuparinen J, Heinanen A (1993) Inorganic nutrient and carbon controlled bacterioplankton growth in the Baltic Sea.
Est Coast Shelf Sci. 37:271-285

Landry MR, Barber RT, Bidigare R, Chai F and 9 others (1997) Iron and grazing constraints on primary production in the central equatorial Pacific: an EqPac synthesis. Limnol Oceanogr 42:405-418

Martin JH, Fitzwater SE (1988) Iron deficiency limits phytoplankton growth in the north-east Pacific Subarctic. Nature 331:341-343

Massana R, Gasol JM, Bjørsen PK, Blackburn N and 5 others (1997) Measurement of bacterial size via image analysis of epifluorescence preparations: description of an inexpensive system and solutions to some of the most common problems. Sci Mar 61:397-407

Massana R, Pedrós-Alió C, Casamayor EO, Gasol JM (2001) Changes in marine bacterioplankton phylogenetic composition during incubations designed to measure biogeochemically significant parameters. Limnol Oceanogr 46: $1181-1188$

Pedrós-Alió C, Calderón-Paz JI, Guixa-Boixereu N, Estrada M, Gasol JM (1999) Bacterioplankton and phytoplankton biomass and production during summer stratification in the northwestern Mediterranean Sea. Deep-Sea Res 46: 985-1019

Pomeroy LR Sheldon JE, Sheldon WM Jr, Peters F (1995) Limits to growth and respiration of bacterioplankton in the Gulf of Mexico. Mar Ecol Prog Ser 117:259-268

Porter KG, Feig YS (1980) The use of DAPI for identifying and counting aquatic microflora. Limnol Oceanogr 25:943-948

Redfield AC (1958) The biological control of chemical factors in the environment. Am Sci 46:205-221

Rivkin RB, Anderson MR (1997) Inorganic nutrient limitation of oceanic bacterioplankton. Limnol Oceanogr 42:730-740

Sala MM, Karner M, Arin L, Marrasé C (2001) Measurement of ectoenzyme activities as an indication of inorganic nutrient imbalance in microbial communities. Aquat Microb Ecol 23:301-311

Smith DC, Azam F (1992) A simple, economical method for measuring bacterial protein synthesis rates in seawater using ${ }^{3} \mathrm{H}$-leucine. Mar Microb Food Webs 6:107-114

Thingstad TF, Rassoulzadegan F (1995) Nutrient limitations, microbial food webs, and 'biological C-pumps': suggested interactions in a P-limited Mediterranean. Mar Ecol Prog Ser 117:299-306

Thingstad TF, Zweifel UL, Rassoulzadegan F (1998) P limitation of heterotrophic bacteria and phytoplankton in the northwest Mediterranean. Limnol Oceanogr 43:88-94

Tyrrell T (1999) The relative influences of nitrogen and phosphorus on oceanic primary production. Nature 400: $525-531$

Tyrrell T, Law CS (1997) Low nitrate:phosphate ratios in the global ocean. Nature 387:793-796

Vaulot D, LeBot N, Marie D, Fukai E (1996) Effect of phosphorus on the Synechococcus cell cycle in surface Mediterranean waters during summer. Appl Environ Microbiol 62:2527-2533

Vidal M, Duarte CM (2000) Nutrient accumulation at different supply rates in experimental Mediterranean planktonic communities. Mar Ecol Prog Ser 207:1-11

Wu JF, Sunda W, Boyle EA, Karl DM (2000) Phosphate depletion in the Western North Atlantic Ocean. Science 289: $759-762$

Zohary T, Robarts RD (1998) Experimental study of microbial $\mathrm{P}$ limitation in the eastern Mediterranean. Limnol Oceanogr 43:387-395

Zweifel UL, Norrman B, Hagström A (1993) Consumption of dissolved organic carbon by marine bacteria and demand for inorganic nutrients. Mar Ecol Prog Ser 101:23-32 